\title{
Nicotinic Receptor Mediates Nitric Oxide Synthase Expression in the Rat Gastric Myenteric Plexus
}

\author{
Kazumi Nakamura, Toku Takahashi, Mayumi Taniuchi, Chun Xiao Hsu, and Chung Owyang \\ Division of Gastroenterology, Department of Internal Medicine, University of Michigan Medical Center, Ann Arbor, Michigan 48109
}

\begin{abstract}
The mechanism that regulates the synthesis of nitric oxide synthase (NOS), a key enzyme responsible for NO production in the myenteric plexus, remains unknown. We investigated the roles of the vagal nerve and nicotinic synapses in the mediation of NOS synthesis in the gastric myenteric plexus in rats. Truncal vagotomy and administration of hexamethonium significantly reduced nonadrenergic, noncholinergic relaxation, the catalytic activity of NOS, the number of NOS-immunoreactive cells, and the density of NOS-immunoreactive bands and NOS mRNA bands obtained from gastric tissue. These results suggest that NOS expression in the gastric myenteric plexus is controlled by the vagal nerve and nicotinic synapses. We also investigated if stimulation of the nicotinic receptor increases neuronal NOS (nNOS) expression in cultured gastric myenteric ganglia. Incubation of cultured gastric myenteric ganglia with the nicotinic receptor agonist, 1,1-dimethyl-4-phenylpiperizinium (DMPP, $10^{-10}-10^{-7} \mathrm{M}$ ), for $24 \mathrm{~h}$ significantly increased the number of nNOS-immunoreactive cells and the density of immunoreactive nNOS bands and nNOS mRNA bands. nNOS mRNA expression stimulated by DMPP was antagonized by a protein kinase $\mathrm{C}$ antagonist, a phospholipase $\mathrm{C}$ inhibitor, and an intracellular $\mathrm{Ca}^{2+}$ chelator. We concluded that activation of the nicotinic receptor stimulates a $\mathrm{Ca}^{2+}$-dependent protein kinase $\mathrm{C}$ pathway, which in turn, upregulates nNOS mRNA expression and nNOS synthesis in the gastric myenteric plexus. (J. Clin. Invest. 1998. 101:1479-1489.) Key words: hexamethonium - truncal vagotomy • protein kinase $\mathrm{C} \cdot$ gene expression • nonadrenergic, noncholinergic relaxation
\end{abstract}

\section{Introduction}

Nitric oxide $(\mathrm{NO})^{1}$ is known to be an important nonadrenergic, noncholinergic (NANC) inhibitory neurotransmitter in the gastrointestinal tract, including the stomach. Neuronal NO synthase (nNOS), a key enzyme responsible for the production of $\mathrm{NO}$, has been detected in the myenteric plexus $(1,2)$ and in the central nervous system (1). It has been reported that nNOS

Address correspondence to Chung Owyang, M.D., The University of Michigan Medical Center, 3912 Taubman Center, Ann Arbor, MI 48109-0362. Phone: 313-936-4785; FAX: 313-936-7392; E-mail: Cowyang @umich.edu

Received for publication 13 May 1997 and accepted in revised form 12 January 1998

J. Clin. Invest.

(C) The American Society for Clinical Investigation, Inc. 0021-9738/98/04/1479/11 \$2.00

Volume 101, Number 7, April 1998, 1479-1489

http://www.jci.org is not detected in the myenteric plexus of patients with achalasia $(3,4)$ or infantile hypertrophic pyloric stenosis $(5)$. The lack of nNOS associated with impaired local production of NO may be one of the factors responsible for the defective sphincter function of the lower esophagus and pylorus in these patients. Recently, we demonstrated that nNOS activity in the gastric myenteric plexus is significantly reduced in spontaneously diabetic BioBreeding/Worcester rats (6). This may be the pathogenic mechanism responsible for the symptoms of early satiety and postprandial fullness often seen in patients with diabetic gastroparesis (7-9). Currently, the mechanism that regulates nNOS synthesis in the myenteric plexus is unknown.

The accommodation reflex, which allows the stomach to receive large volumes during food intake with only minimal increases in pressure, was first reported by Cannon and Lieb in 1911 (10). This reflex appears to be mediated by the vagovagal reflex, which involves the vagal afferent and efferent pathways. The preganglionic vagal fibers activate postganglionic elements in the gastric wall, which release NANC neurotransmitters in the gastric myenteric plexus that in turn mediate gastric relaxation (11-16). Recently, we demonstrated that the accommodation reflex involves the vagal efferent pathway and nicotinic synapses, using NO released from the gastric myenteric plexus as the final neurotransmitter to mediate gastric relaxation (17). It has been reported that the accommodation reflex is impaired after vagotomy and in patients with functional dyspepsia. Troncon et al. (18) have shown that patients with functional dyspepsia have a low vagal tone. An NO donor, glyceryl trinitrate, reduces abnormal antral filling in patients with functional dyspepsia, suggesting that the NO pathway is impaired in these patients (18).

In this study, we investigated if the synthesis and gene expression of nNOS in the gastric myenteric plexus are controlled by the vagal nerve and nicotinic synapses. We evaluated NANC relaxation of gastric muscle strips and the number of nNOS-immunoreactive cells and NADPH diaphorase-positive cells in the gastric myenteric plexus after vagotomy or nicotinic receptor blockade. The quantitative changes of nNOS synthesis in the myenteric plexus after vagotomy or nicotinic receptor blockade were studied by ${ }^{3} \mathrm{H}$-citrulline assay and Western blot analysis. We also investigated changes in nNOS mRNA expression in the gastric myenteric plexus after vagotomy or nicotinic receptor blockade using Northern blot analysis.

To further demonstrate that stimulation of the nicotinic receptor mediates nNOS synthesis, we isolated the gastric myen-

1. Abbreviations used in this paper: $\left[\mathrm{Ca}^{2+}\right]_{\mathrm{i}}$, intracellular $\mathrm{Ca}^{2+} ; \mathrm{DMPP}$, 1,1-dimethyl-4-phenylpiperizinium; eNOS, endothelial NOS; iNOS, inducible form of NOS; L-NAME, $N^{\mathrm{G}}$-nitro-L-arginine methyl ester; NANC, nonadrenergic, noncholinergic; nNOS, neuronal nitric oxide synthase; NO, nitric oxide; NOS, nitric oxide synthase; PGP, protein gene product; $\mathrm{PKC}$, protein kinase $\mathrm{C}$; SNP, sodium nitroprusside; TTX, tetrodotoxin. 
teric plexus in neonatal rats by collagenase digestion and cultured the ganglia in the absence and presence of the nicotinic receptor agonist, 1,1-dimethyl-4-phenylpiperizinium (DMPP). We also studied the intracellular mechanisms responsible for nNOS mRNA expression in response to nicotinic receptor stimulation.

\section{Methods}

Animal preparation. Male Sprague-Dawley rats (body wt, 250-280 g) were fasted overnight and anesthetized by intramuscular injection of xylazine and ketamine (13 and $87 \mathrm{mg}$ per kg body wt, respectively). To investigate the involvement of the vagal nerve in the mediation of nNOS synthesis in the gastric myenteric plexus, bilateral abdominal truncal vagotomy was performed. Sham-operated rats served as controls. $3 \mathrm{~d}$ after the operation, rats were killed for in vitro studies. To investigate the involvement of the nicotinic receptor in the mediation of nNOS synthesis, rats were treated with hexamethonium for $3 \mathrm{~d}$ (40 $\mathrm{mg} / \mathrm{kg} / \mathrm{d}$, intraperitoneally). Rats injected with saline (400 $\mu \mathrm{l}$ per rat, intraperitoneally) served as controls. This dose of hexamethonium was chosen because $40 \mathrm{mg} / \mathrm{kg}$ (intraperitoneally) has been shown to block nifedipine-induced hyperglycemia in streptozotocin-induced diabetic rats in vivo (19). The effectiveness of hexamethonium administration was confirmed by demonstrating that the gastric motor response to vagal stimulation was abolished in hexamethoniumtreated rats, as reported previously (20).

NANC relaxation in response to transmural stimulation. $3 \mathrm{~d}$ after vagotomy, circular muscle strips from the anterior wall of the gastric body were prepared. As described previously $(21,22)$, muscle strips (8-mm long, 3-mm wide) were suspended between two platinum electrodes in a $20-\mathrm{ml}$ organ bath filled with Krebs-Henseleit buffer. Mechanical activity was recorded on a polygraph using isometric transducers. Muscle strips were stretched in $1-\mathrm{mm}$ increments and repeatedly exposed to carbachol $\left(10^{-6} \mathrm{M}\right)$ to determine $\mathrm{L}_{\mathrm{O}}$, the length at which maximal active tension developed. Dose-response curves were constructed for each muscle strip for sodium nitroprusside (SNP, $10^{-8}-10^{-5} \mathrm{M}$ ), an activator of soluble guanylate cyclase, and carbachol $\left(10^{-8}-10^{-5} \mathrm{M}\right)$. To study NANC relaxation, muscle strips were stimulated for $30 \mathrm{~s}$ by transmural electrical stimulation $(65 \mathrm{~V}, 1 \mathrm{~ms}$, $1-10 \mathrm{~Hz})$ in the presence of atropine $\left(10^{-6} \mathrm{M}\right)$ and guanethidine $\left(10^{-6}\right.$ M). All experiments were performed using muscle strips stimulated by 5 -hydroxytryptamine $\left(10^{-5} \mathrm{M}\right)$ to evaluate the inhibitory effects of NO, as described previously (23). Tensions were expressed per crosssectional area of each muscle strip and were calculated from the equation: Cross-section $\left(\mathrm{mm}^{2}\right)=$ tissue weight $(\mathrm{mg}) / L_{\mathrm{O}}(\mathrm{mm}) \times$ density; where $\mathrm{L}_{\mathrm{O}}$ is the optimum length, and the density of smooth muscle is $1.05 \mathrm{mg} / \mathrm{mm}^{3}(6,24)$. To study NO-dependent relaxation, the muscle strips were exposed to transmural stimulation in the presence of atropine $\left(10^{-6} \mathrm{M}\right)$, guanethidine $\left(10^{-6} \mathrm{M}\right)$, and $N^{\mathrm{G}}$-nitro-L-arginine methyl ester (L-NAME) $\left(10^{-4} \mathrm{M}\right)$. Gastric muscle strips from control rats demonstrated frequency-dependent relaxation in response to transmural stimulation $(1-10 \mathrm{~Hz})$. This relaxation was completely abolished by tetrodotoxin (TTX) $\left(10^{-7} \mathrm{M}\right)$ (data not shown), which indicated mediation by a neural pathway. We have shown recently that L-NAME $\left(10^{-4} \mathrm{M}\right)$ significantly reduced NANC relaxation induced by 1 and $2.5 \mathrm{~Hz}$, by 95 and $80 \%$, respectively, suggesting that the muscle relaxation was primarily mediated by NO synthesis in the myenteric plexus in rat stomach (6). On the other hand, L-NAME reduced NANC relaxation induced by 5 and $10 \mathrm{~Hz}$ by 60 and $50 \%$, respectively, indicating partial mediation by NO (6). The effect of transmural stimulation $(1 \mathrm{~Hz})$ on L-NAME-sensitive NANC relaxation was compared between the muscle strips from sham-operated and vagotomized rats, and vehicle-treated and hexamethoniumtreated rats. We have demonstrated previously that DMPP $\left(10^{-6}\right.$ $10^{-4} \mathrm{M}$ ) caused L-NAME-sensitive relaxation of the gastric muscle in vitro (20). The L-NAME-sensitive relaxation induced by DMPP $\left(10^{-5} \mathrm{M}\right)$ was compared between the muscle strips from sham-oper- ated and vagotomized rats, and vehicle-treated and hexamethoniumtreated rats.

Catalytic activity of nNOS. Gastric muscle strips from shamoperated rats, vagotomized rats, vehicle-treated rats, and hexamethonium-treated rats were quickly frozen in liquid nitrogen, powdered in a mortar kept at $-80^{\circ} \mathrm{C}$, and homogenized in Hepes $(50 \mathrm{mM}, \mathrm{pH} 7.4)$ containing EGTA $(0.1 \mathrm{mM})$, DTT $(1 \mathrm{mM})$, leupeptin $(10 \mu \mathrm{g} / \mathrm{ml})$, aprotinin $(10 \mu \mathrm{g} / \mathrm{ml})$, PMSF $(1 \mathrm{mM})$, and Triton X-100 (0.1\%). After centrifugation at $14,000 \mathrm{~g}$ for $15 \mathrm{~min}$ at $4^{\circ} \mathrm{C}$, the supernatant was incubated with $\mathrm{L}-\left[{ }^{3} \mathrm{H}\right]$-arginine $(3 \mu \mathrm{Ci} / \mathrm{ml})$ for $6 \mathrm{~min}$ at $37^{\circ} \mathrm{C}$ in the presence of cofactors and substrates $(1 \mathrm{mM}$ NADPH, $1 \mu \mathrm{M}$ flavin adenine dinucleotide, $1 \mu \mathrm{M}$ flavin mononucleotide, $1 \mu \mathrm{M}$ tetrahydrobiopterin, $1.25 \mathrm{mM} \mathrm{CaCl}_{2}$, and $10 \mu \mathrm{M} \mathrm{L}$-arginine). Protein contents in the supernatant were measured by the Bio-Rad method using BSA (BioRad Laboratories, Richmond, CA). L- $\left[{ }^{3} \mathrm{H}\right]$-Citrulline in the sample was extracted with diethyl ether and an aliquot was applied to a Dowex AG50W-X8 column (sodium form) and eluted with distilled water. $\mathrm{L}-\left[{ }^{3} \mathrm{H}\right]$-Citrulline in the effluent was measured by liquid scintillation spectroscopy. The production of L- $\left[{ }^{3} \mathrm{H}\right]$-citrulline, stoichiometrically equivalent to $\mathrm{NO}$, was expressed as picomoles per milligram of protein per minute. Chromatography showed retention of $98.2 \%$ of L- $\left[{ }^{3} \mathrm{H}\right]$-arginine in the resin. L-NAME inhibited the conversion of L-arginine to L-citrulline by $>95 \%$. ${ }^{3} \mathrm{H}$-Citrulline formation was compared between the muscle tissues from sham-operated and vagotomized rats, and vehicle-treated and hexamethonium-treated rats.

NADPH diaphorase histochemistry. As previously reported, NADPH diaphorase-positive neuronal cell bodies and fibers were found throughout the entire rat gastrointestinal tract, including the stomach $(2,25)$. Most of the myenteric neurons in all regions of the gut that were NOS positive also stained for NADPH diaphorase (25). Tissue from the anterior wall of the gastric body was obtained from sham-operated rats, vagotomized rats, vehicle-treated rats, and hexamethonium-treated rats. After the removal of mucosa, whole muscle layers were fixed overnight in $4 \%$ paraformaldehyde at $4^{\circ} \mathrm{C}$. Histochemical staining for NADPH diaphorase was performed using the method described by Aimi et al. (2). NADPH diaphorase activity was rendered visible by incubating the tissue in $0.1 \mathrm{M}$ phosphate buffer ( $\mathrm{pH} 8.0$ ) containing $0.01 \mathrm{mM} \beta-\mathrm{NADPH}, 0.02 \mathrm{mM}$ nitroblue tetrazolium, and $0.3 \%$ Triton $\mathrm{X}-100$ at $37^{\circ} \mathrm{C}$ for $2 \mathrm{~h}$. The reaction was terminated by washing the whole mount layer in $0.1 \mathrm{M}$ phosphate buffer. After several washes in $0.1 \mathrm{M}$ phosphate buffer, the whole muscle layers were placed on glass slides, air-dried, and cover-slipped with gelmount. The number of NADPH diaphorase-positive cells in 50 ganglia was counted in each preparation and expressed as the average number of NADPH diaphorase-positive cells per ganglion, as previously described (6).

nNOS immunohistochemistry. Tracey et al. (26) demonstrated that NADPH diaphorase activity does not always colocalize with nNOS activity. This suggests that NADPH diaphorase may not be nNOS. Therefore, we also performed immunohistochemistry using nNOS antibody to detect neurons containing nNOS in the gastric myenteric plexus. Animals that had undergone vagotomy or sham operation previously were anesthetized with pentobarbital and perfused with $300 \mathrm{ml}$ of $0.15 \mathrm{M}$ PBS (pH 7.4), followed by $300 \mathrm{ml}$ of ice-cold fixative consisting of $4 \%$ paraformaldehyde in $0.15 \mathrm{M}$ PBS. Tissue from the anterior wall of the gastric body was removed. Each $5-\mu \mathrm{m}$ section of paraffin-embedded tissue was washed three times with PBS, 5 min each time. Sections were blocked for $1 \mathrm{~h}$ in $0.15 \mathrm{M}$ PBS containing $4 \%$ normal goat serum and $0.2 \%$ Triton X-100 and incubated with antisera raised in rabbits against purified, soluble NOS extract from rat cerebellum (nNOS antibody; Euro-Diagnostica, Malmo, Sweden) at a dilution of $1: 1,000$ in PBS for $18 \mathrm{~h}$ at $4^{\circ} \mathrm{C}$. After washing in PBS, sections were incubated with biotinylated anti-rabbit IgG for $1 \mathrm{~h}$ at room temperature. Sections were stained with horseradish peroxidase using an avidin-biotin labeled kit (Vectastain ABC kit). Diaminobenzidine and nickel chloride were used as chromogens. The total number of nNOS-immunoreactive cells in the myenteric plexus was counted microscopically and expressed as the number of immunore- 
active cells per millimeter length of muscle strip, as previously described (6).

Protein gene product (PGP) 9.5 immunohistochemistry. It has been demonstrated that antisera raised against neuronal cytosolic protein, PGP 9.5, stain generic neurons in the central nervous system and the myenteric plexus (27). To investigate the effect of vagotomy on the number of generic neurons, we performed immunohistochemical staining of myenteric neurons using antisera to PGP 9.5.

Western blot analysis of nNOS synthesis. Gastric tissue was obtained from sham-operated and vagotomized rats. Soluble homogenates of these samples were prepared in lysis buffer containing $25 \mathrm{mM}$ Tris-HCl (pH 7.4), EGTA (1 mM), DTT (1 mM), leupeptin $(10 \mu \mathrm{g} / \mathrm{ml})$, aprotinin $(10 \mu \mathrm{g} / \mathrm{ml})$, PMSF $(1 \mathrm{mM})$, and Triton X-100 (0.1\%). Western blot analysis of the gastric tissue was performed as described by Matsumoto et al. (28). Protein (each sample, $20 \mu \mathrm{g}$ ) was separated by SDS-PAGE $(7.5 \% \mathrm{wt} / \mathrm{wt}$ gel) and transferred to a nitrocellulose membrane. All procedures were done in Tris buffer $(40 \mathrm{mM}, \mathrm{pH}$ 7.55 ) containing $0.3 \mathrm{M} \mathrm{NaCl}$ and $0.3 \%$ Tween 20 . The membrane was blocked with dried milk ( $6 \% \mathrm{wt} / \mathrm{vol})$, and subsequently incubated with specific polyclonal nNOS antibody (1:1,000 dilution) and a horseradish peroxidase conjugate of affinity-purified goat antibody to rabbit IgG. The immune complexes were detected on photographic film by $\mathrm{H}_{2} \mathrm{O}_{2}$ /luminol chemiluminescence and the band density was measured by an imaging analyzer.

Northern blot analysis of NOS mRNA expression. For Northern blot analysis, total RNA was isolated from homogenized gastric tissue from sham-operated rats, vagotomized rats, vehicle-treated rats, and hexamethonium-treated rats. Extraction and preparation of RNA was performed using TRIzol reagent. The amount of RNA was estimated by measuring absorbance at $260 \mathrm{~nm}$. After isolation, the total RNA samples (each sample, $20 \mu \mathrm{g}$ ) were electrophoresed on an agarose gel and transferred onto a nylon membrane. As demonstrated by Huang et al. (29), we used $2947 \mathrm{~b}$ rat neuronal NOS cDNA probe that extends $2.1 \mathrm{~kb}$ in the $3^{\prime}$ direction beyond the first exon (244-3191) of the cloned cDNA (30). This probe was made from the original cDNA (provided by Dr. S.H. Snyder) cut by the restriction endonuclease AatII. The cDNA probe $(2.9 \mathrm{~kb})$ was labeled with $\left[{ }^{32} \mathrm{P}\right] \mathrm{dCTP}(111$ $\mathrm{TBq} / \mathrm{mmol}$ ) by the random-primed labeling method. The samples were prehybridized at $65^{\circ} \mathrm{C}$ for $3 \mathrm{~h}$ and hybridized with the labeled probes at $65^{\circ} \mathrm{C}$ for $16 \mathrm{~h}$. The samples were washed twice for $5 \mathrm{~min}$ each time in $2 \times \mathrm{SSC}, 0.1 \%$ SDS at $65^{\circ} \mathrm{C}$, followed by two 5 -min washes in $0.2 \times \mathrm{SSC}, 0.1 \%$ SDS at $65^{\circ} \mathrm{C}$. Equivalent loading of RNA in the various lanes was confirmed by washing the membranes and rehybridizing them with a probe against glyceraldehyde-3-phosphate dehydrogenase. Autoradiography was performed with intensifying screens at $-80^{\circ} \mathrm{C}$. The density of radioactivity was measured by an imaging analyzer.

Culture of isolated gastric myenteric ganglia. Our preliminary studies showed that there is a similar distribution of NADPH diaphorasepositive cells and nNOS-immunopositive cells in the myenteric plexus in gastric tissue from adult and neonatal rats. L-NAME antagonized NANC relaxation in gastric muscle strips obtained from adult and neonatal rats. Because isolated ganglia from adult rats are difficult to grow in culture, we used isolated ganglia from neonatal rats for the cell culture. The gastric muscle layers obtained from neonatal rats were stretched on a silicone-coated Petri dish containing HBSS and kept at $4^{\circ} \mathrm{C}$ for $30 \mathrm{~min}$. The tissue was minced and incubated for 20 min at $37^{\circ} \mathrm{C}$ in HBSS containing $0.2 \%$ collagenase (type II) and $0.2 \%$ protease (type IX), as previously reported (31). At the end of this period, the partially digested tissue was mechanically disrupted by repeated suction into a 5-ml pipette to free the ganglia. The suspension was centrifuged for $4 \mathrm{~min}$ at $200 \mathrm{~g}$. The supernatant containing dispersed muscle cells was discarded and the pellet containing ganglia was resuspended in HBSS and filtered through Nitex $(500 \mu \mathrm{m})$. The ganglia were placed in tissue culture wells coated with Matrigel (1:5 dilution). The explants were exposed to a defined culture medium that contained DME supplemented with $10 \%$ rat serum (heat-inactivated), nerve growth factor $(50 \mathrm{ng} / \mathrm{ml})$, penicillin-streptomycin solu- tion $(100 \mathrm{U} / \mathrm{ml})$, and cytosine arabinoside $\left(10^{-5} \mathrm{M}\right)$. Cytosine arabinoside has been shown to eliminate nonneuronal cells of cultured neonatal rat sympathetic neurons $(32,33)$ and cultured adult guinea pig myenteric plexus (34). This mitotic inhibitor has been shown to strongly inhibit the proliferation of nonneuronal cells in culture, without influencing the regulation of neuronal gene expression (35). The culture medium was changed every second day. The myenteric ganglia were cultured for $5 \mathrm{~d}$ with cytosine arabinoside and used in the following experiments.

To confirm the viability of the cultured neurons, we measured intracellular $\mathrm{Ca}^{2+}\left(\left[\mathrm{Ca}^{2+}\right]_{\mathrm{i}}\right)$ using a single neuron preloaded with fura-2, a fluorescent $\mathrm{Ca}^{2+}$ indicator, as described previously (31). Cells were stimulated by $\mathrm{KCl}(60 \mathrm{mM})$ or DMPP $\left(10^{-4} \mathrm{M}\right)$ for 15 s every $5 \mathrm{~min}$. $\left[\mathrm{Ca}^{2+}\right]_{\mathrm{i}}$ in response to $\mathrm{KCl}$ or DMPP was measured using a dual wavelength modulator fluorometer.

To investigate if nicotinic receptors stimulate nNOS expression, cultured myenteric ganglia were incubated with DMPP $\left(10^{-10}-10^{-6} \mathrm{M}\right)$ or vehicle for 6-72 $\mathrm{h}$. The cells were subjected to nNOS immunocytochemistry, Western blot analysis of nNOS, and Northern blot analysis of nNOS mRNA.

Materials. Atropine, aprotinin, collagenase (type II), diaminobenzidine, flavin adenine dinucleotide, flavin mononucleotide, guanethidine, leupeptin, NADPH (reduced form), nitroblue tetrazolium, TTX, Triton X, protease (type IX), and PMSF were obtained from Sigma Chemical Co. (St. Louis, MO). Tetrahydrobiopterin was obtained from ICN (Costa Mesa, CA). L-NAME was obtained from Research Biochemicals (Natick, MA). L- $\left[{ }^{3} \mathrm{H}\right]$-Arginine was obtained from New England Nuclear (Boston, MA). Dowex AG50W-X8 was obtained from Bio-Rad Laboratories. Antibody to constitutive nNOS was obtained from Euro-Diagnostica. Antibody to PGP 9.5 was obtained from Ultraclone (Isle of Wight, United Kingdom). Anti-rabbit $\mathrm{IgG}$ and an avidin-biotin labeled kit were obtained from Vector Laboratories (Burlingame, CA). $\left.{ }^{32} \mathrm{P}\right] \mathrm{dCTP}$ and the random-primer labeling (Rediprime) were obtained from Amersham (Arlington Heights, IL). TRIzol was obtained from Life Technologies (Gaithersburg, MD). AatII and DTT were obtained from Boehringer Mannheim (Indianapolis, IN). Matrigel was obtained from Collaborative Biomedical Products (Bedford, MA). Genistein and U73122 were obtained from Biomol (Plymouth Meeting, PA). PMA, BAPTA/AM, and bisindolylmaleimide were obtained from Calbiochem (San Diego, CA).

Statistical analysis. Statistical analysis was performed by Student's $t$ test. Bonferroni's correction was used for multiple $t$ tests. $P<$ 0.05 was considered significant.

\section{Results}

$N A N C$ relaxation. Transmural stimulation caused a frequencydependent NANC relaxation in the presence of atropine and guanethidine in the preparations from sham-operated rats (Fig. $1 a$ and Fig. $2 a$ ) and vehicle-treated rats. As previously described (6), NANC relaxation was significantly antagonized by L-NAME and abolished by TTX (data not shown), which suggests mediation by neural release of NO from the gastric myenteric plexus. The L-NAME-sensitive component of the NANC relaxation induced by transmural stimulation $(1 \mathrm{~Hz})$ was significantly impaired in the muscle strips from vagotomized rats (Fig. $1 b$ and Fig. $2 a$ ) and hexamethonium (C6)treated rats (Fig. $2 a$ ). However, muscle relaxation induced by exogenous SNP $\left(10^{-6} \mathrm{M}\right)$ remained unaffected in the preparations from vagotomized rats (Fig. $1 b$ and Fig. $2 b$ ) and hexamethonium-treated rats (Fig. $2 b$ ).

L-NAME-sensitive relaxation evoked by DMPP $\left(10^{-5} \mathrm{M}\right)$ was $0.52 \pm 0.07 \mathrm{~g} / \mathrm{mm}^{2}$ in the gastric muscle strips from shamoperated rats and $0.48 \pm 0.06 \mathrm{~g} / \mathrm{mm}^{2}$ in the gastric muscle strips 


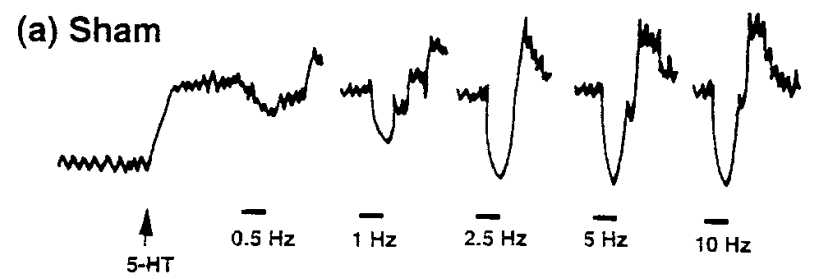

(b) Vagotomy

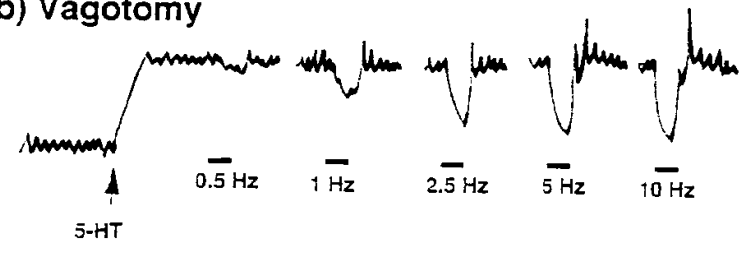

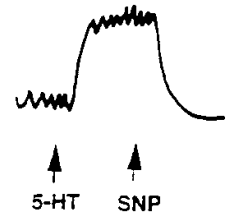

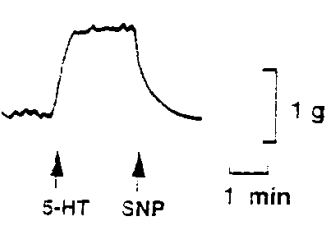

Figure 1. NANC relaxation in response to transmural stimulation $(65 \mathrm{~V}, 1 \mathrm{~ms}, 1-10$ $\mathrm{Hz})$ and $\mathrm{SNP}\left(10^{-6} \mathrm{M}\right)$-induced relaxation in the gastric muscle strips from shamoperated rats $(a)$ and vagotomized rats $(b)$. NANC relaxation was significantly reduced in the muscle strips from vagotomized rats. SNP induced a similar relaxation in shamoperated rats and vagotomized rats. from vehicle-treated rats. L-NAME-sensitive relaxation evoked by DMPP $\left(10^{-5} \mathrm{M}\right)$ was significantly reduced in vagotomized rats $\left(0.23 \pm 0.03 \mathrm{~g} / \mathrm{mm}^{2}\right)$ and hexamethonium-treated rats $\left(0.25 \pm 0.04 \mathrm{~g} / \mathrm{mm}^{2}\right)($ mean \pm SE, $n=4, P<0.05)$.

NOS catalytic activity. ${ }^{3} \mathrm{H}$-Citrulline formation was $0.18 \pm$ $0.03 \mathrm{pmol} / \mathrm{mg}$ protein $/ \mathrm{min}$ in the gastric muscle tissue from sham-operated rats and $0.20 \pm 0.04 \mathrm{pmol} / \mathrm{mg}$ protein $/ \mathrm{min}$ in the gastric tissue from vehicle-treated rats. ${ }^{3} \mathrm{H}$-Citrulline formation was significantly reduced in vagotomized rats $(0.09 \pm 0.01$ $\mathrm{pmol} / \mathrm{mg}$ protein $/ \mathrm{min}$ ) and hexamethonium-treated rats $(0.08 \pm 0.01 \mathrm{pmol} / \mathrm{mg}$ protein $/ \mathrm{min})($ mean $\pm \mathrm{SE}, n=8, P<$ $0.05)$.

NADPH diaphorase histochemistry. The NADPH diaphorase-positive cells and fibers were clearly observed in the gastric myenteric plexus of the sham-operated rats (Fig. $3 a$ ) and vehicle-treated rats (Fig. $3 c$ ). The number of NADPH diaphorase-positive cells in the gastric myenteric plexus was significantly reduced in the muscle strips from vagotomized rats (Fig. $3 b$ ) and hexamethonium-treated rats (Fig. $3 d$ ). The average number of NADPH diaphorase-positive cells was

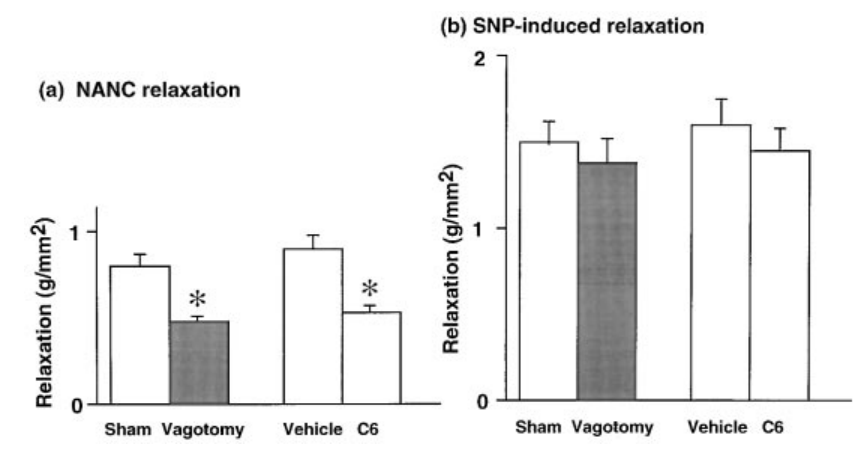

Figure 2. L-NAME-sensitive NANC relaxation in response to transmural stimulation $(65 \mathrm{~V}, 1 \mathrm{~ms}, 1 \mathrm{~Hz})(a)$ and $\mathrm{SNP}\left(10^{-6} \mathrm{M}\right)$-induced relaxation $(b)$ in the gastric muscle strips from sham-operated rats, vagotomized rats, vehicle-treated rats, and hexamethonium (C6)treated rats. L-NAME-sensitive NANC relaxation was significantly reduced in the muscle strips from vagotomized rats and hexamethonium (C6)-treated rats. SNP-induced relaxation remained unaffected in vagotomized rats and hexamethonium (C6)-treated rats (mean \pm SE, $n=4, * P<0.05$ ).
4.6 \pm 0.6 cells per ganglion in sham-operated and vehicletreated rats $(n=6)$. The number was significantly reduced in the muscle strips from vagotomized rats and hexamethoniumtreated rats to $2.5 \pm 0.7$ and $2.4 \pm 0.8$ cells per ganglion, respectively $(P<0.05, n=6)$.

$n N O S$ immunohistochemistry. nNOS-immunoreactive neuronal cell bodies were found throughout the myenteric plexus in the gastric body of sham-operated rats. Nonneuronal tissues such as muscle cells, endothelia, mucosal cells, and macrophages were unstained. NOS-immunoreactive neuronal fibers were abundant in the circular muscle layers (Fig. $4 A$ ). In contrast, the numbers of nNOS-immunoreactive cells and fibers were significantly reduced in vagotomized rats (Fig. $4 \mathrm{~B}$ ). The average number of nNOS-immunoreactive cells was 0.94 $0.12 / \mathrm{mm}$ in sham-operated rats $(n=3)$. This was significantly reduced to $0.51 \pm 0.08 / \mathrm{mm}$ in vagotomized rats $(P<0.01, n=3)$.

PGP 9.5 immunohistochemistry. The number of PGP 9.5immunoreactive cells in the gastric myenteric plexus was not significantly different between the muscle strips from shamoperated rats (Fig. $4 C$ ) and vagotomized rats (Fig. $4 D$ ).

Western blot analysis of nNOS synthesis in gastric tissue. The molecular masses of nNOS and endothelial NOS (eNOS) have been shown to be 155 and $130 \mathrm{kD}$, respectively (36). To investigate any changes in nNOS synthesis in the gastric myenteric plexus in vagotomized rats, we performed Western blot analysis using nNOS antibody. The nNOS-immunoreactive bands at $155 \mathrm{kD}$ obtained from gastric tissue corresponded well with those from rat cerebellum. The density of nNOSimmunoreactive bands $(155 \mathrm{kD})$ was clearly observed in gastric tissue from sham-operated rats, and was significantly reduced to $53 \pm 6 \%$ in gastric tissue from vagotomized rats (Fig. 5).

Northern blot analysis of nNOS mRNA in gastric tissue. We investigated whether reduced nNOS synthesis in the gastric myenteric plexus in vagotomized rats and hexamethonium-treated rats is caused by reduced nNOS mRNA expression. The size of nNOS mRNA and eNOS mRNA has been demonstrated to be 9.5 and $4.5 \mathrm{~kb}$, respectively (36). nNOS mRNA expression $(9.5 \mathrm{~kb})$ was clearly observed in the gastric tissue from sham-operated rats and vehicle-treated rats. As shown in Fig. 6, the nNOS mRNA bands obtained from gastric tissue correspond well with the bands obtained from rat cerebellum. The density of nNOS mRNA of gastric tissue obtained from vagotomized rats and hexamethonium-treated rats was 


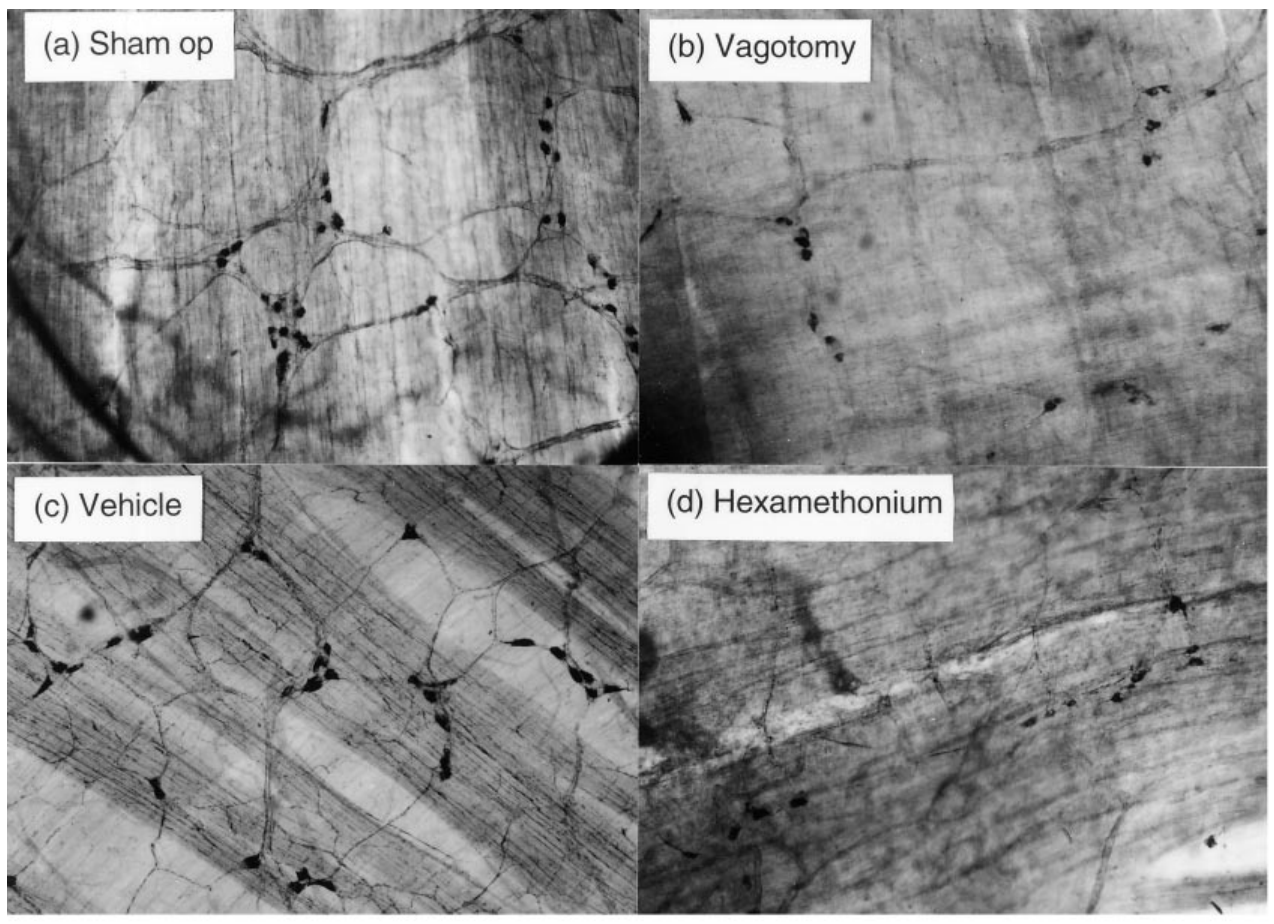

$\overline{100 \mu \mathrm{m}}$
Figure 3. NADPH diaphorase histochemistry in whole mount preparations of gastric muscle tissue from sham-operated rats $(a)$, vagotomized rats $(b)$, vehicle-treated rats $(c)$, and hexamethonium-treated rats $(d)$. The number of NADPH diaphorase-positive cells in the gastric myenteric plexus was significantly reduced in the muscle strips from vagotomized rats and hexamethonium-treated rats. Bar $=100 \mu \mathrm{m}$. significantly reduced compared with that obtained from shamoperated rats and vehicle-treated rats. The density of glyceraldehyde-3-phosphate dehydrogenase bands of the gastric tissue was not significantly different among sham-operated rats, va- gotomized rats, vehicle-treated rats, and hexamethoniumtreated rats (data not shown).

Isolation of gastric myenteric plexus. Approximately 1,000 myenteric ganglia were harvested from each neonatal rat. No
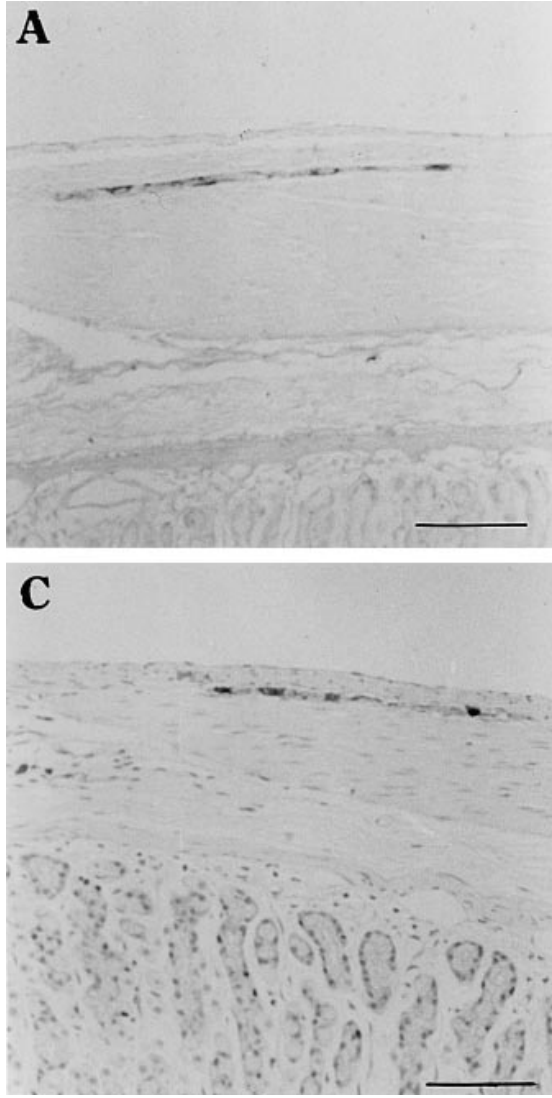

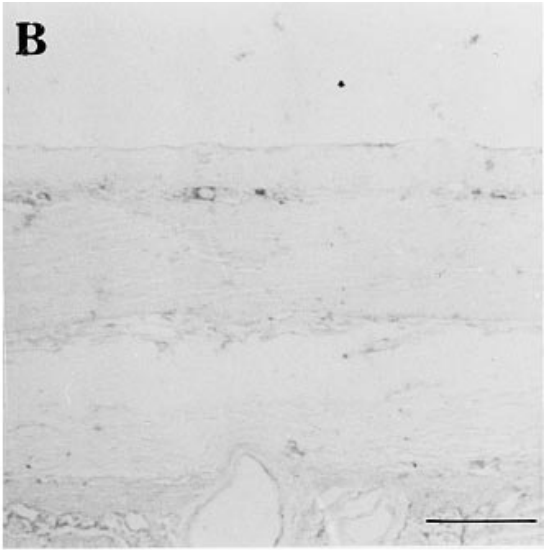

D

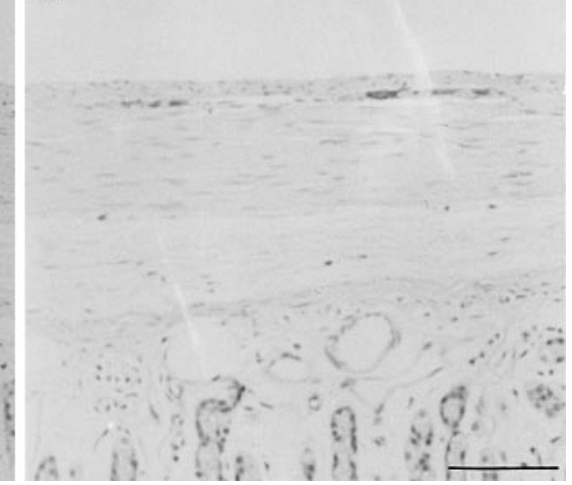

Figure 4. nNOS immunohistochemistry of gastric muscle tissue obtained from sham-operated rats $(A)$ and vagotomized rats $(B)$. PGP 9.5 immunohistochemistry of the gastric muscle tissues from sham-operated rats $(C)$ and vagotomized rats $(D)$. The number of NOS-immunoreactive cells in the gastric myenteric plexus was significantly reduced in the muscle strips from vagotomized rats, compared with sham-operated rats. In contrast, the number of PGP 9.5-immunoreactive cells in the gastric myenteric plexus of the muscle strips from vagotomized rats was not affected. Bar $=50 \mu \mathrm{m}$. 


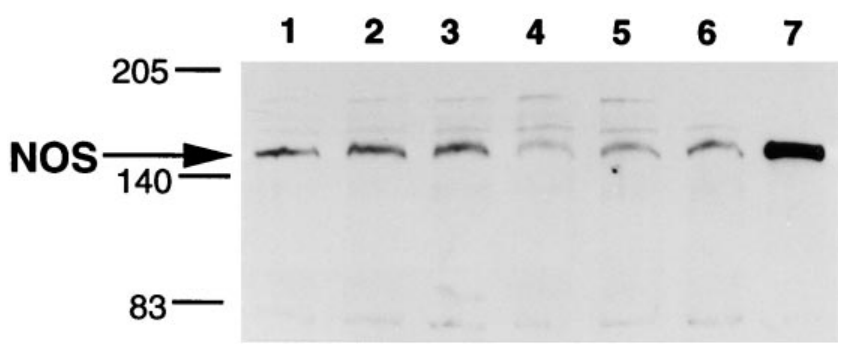

Figure 5. Western blot analysis of nNOS of the gastric tissues obtained from sham-operated rats (lanes 1-3) and vagotomized rats (lanes 4-6). The nNOS-immunoreactive bands at $155 \mathrm{kD}$ obtained from gastric tissues corresponded well with those obtained from rat cerebellum (lane 7). The density of nNOS-immunoreactive bands $(155 \mathrm{kD})$ obtained from gastric tissue of vagotomized rats was significantly reduced to $53 \pm 6 \%($ mean $\pm \mathrm{SE}, n=4, P<0.05)$.

contamination of smooth muscle cells was observed. $\mathrm{KCl}(60$ $\mathrm{mM})$ or DMPP $\left(10^{-4} \mathrm{M}\right)$ increased $\left[\mathrm{Ca}^{2+}\right]_{\mathrm{i}}$ spiking in single neurons preloaded with fura-2, with increases of $165 \pm 28$ and $105 \pm 19 \mathrm{nM}$, respectively (mean \pm SE, $n=6$ ).

nNOS immunocytochemistry of isolated cultured myenteric plexus. The number of nNOS-immunoreactive cells in each ganglion was counted under a microscope (magnification $\times 100$ ). 30 ganglia were counted. Incubation for $24 \mathrm{~h}$ with DMPP $\left(10^{-8} \mathrm{M}\right)$ significantly increased the number of nNOSimmunoreactive cells in isolated myenteric ganglia (Fig. 7). The average number of nNOS-immunoreactive cells in the control was $7.6 \pm 1.7$ cells per ganglion. Incubation with DMPP $\left(10^{-8} \mathrm{M}\right)$ for $24 \mathrm{~h}$ increased the number of nNOS-immunoreactive cells to $13.7 \pm 2.2$ cells per ganglion. Incubation with PMA $\left(10^{-7} \mathrm{M}\right)$ for $6 \mathrm{~h}$ also increased the number of nNOS-immunoreactive cells, from $7.4 \pm 1.4$ to $16.0 \pm 2.0$ cells per ganglion.

Western blot analysis of nNOS synthesis in the cultured gas- (a)

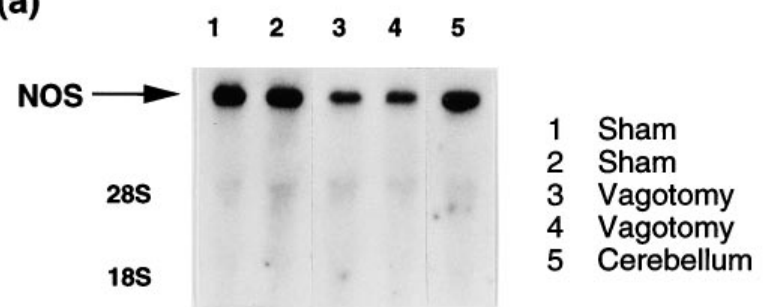

(b)

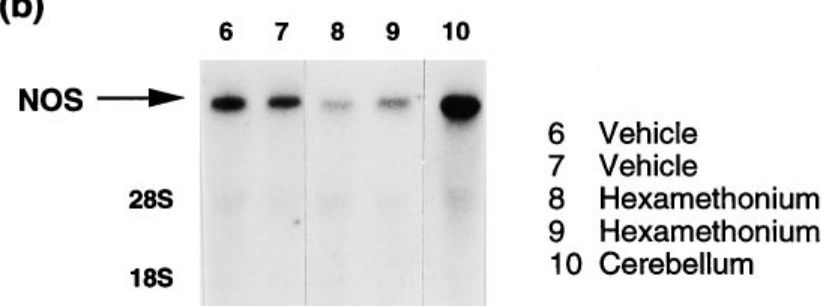

Figure 6. Northern blot analysis of nNOS mRNA in gastric tissue from sham-operated rats (lanes 1 and 2) and vagotomized rats (lanes 3 and 4) (a). Northern blot analysis of NOS mRNA in gastric tissue from vehicle-treated rats (lanes 6 and 7) and hexamethonium-treated rats (lanes 8 and 9) (b). nNOS mRNA in cerebellum was used as a positive control (lanes 5 and 10). nNOS mRNA expression in gastric tissue from vagotomized rats and hexamethonium-treated rats was significantly reduced (56 \pm 7 and $49 \pm 8 \%$, respectively) compared with sham-operated rats and vehicle-treated rats (mean \pm SE, $n=4$, $P<0.05)$.

tric myenteric plexus. To quantify the amount of nNOS formed in the gastric myenteric plexus in response to DMPP, Western blot analysis of nNOS was performed. As shown in Fig. 8, incubation with DMPP $\left(10^{-8} \mathrm{M}\right)$ for $24 \mathrm{~h}$ caused a significant in-

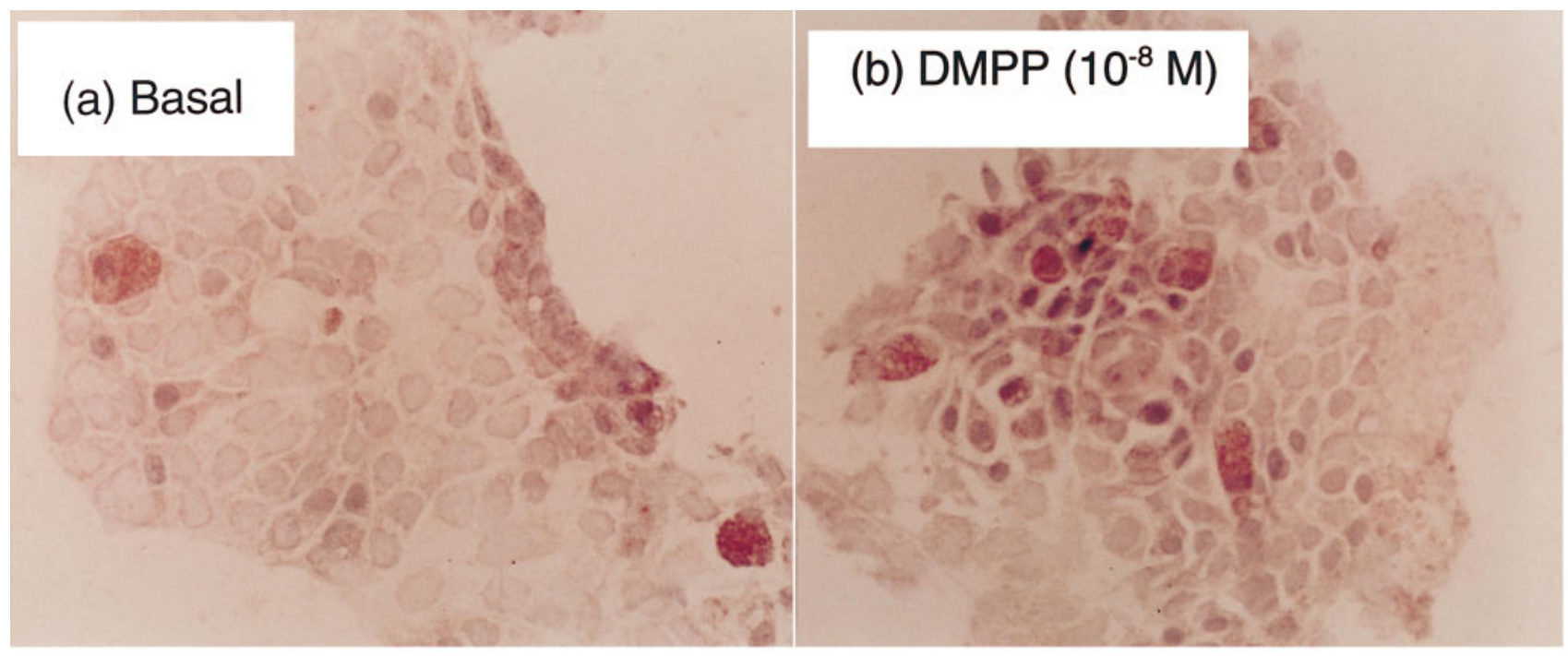

$50 \mu \mathrm{m}$

Figure 7. nNOS immunocytochemistry of cultured myenteric ganglia in the absence $(a)$ or presence $(b)$ of DMPP $\left(10^{-8} \mathrm{M}\right)$. Bar $=50 \mu \mathrm{m}$. 


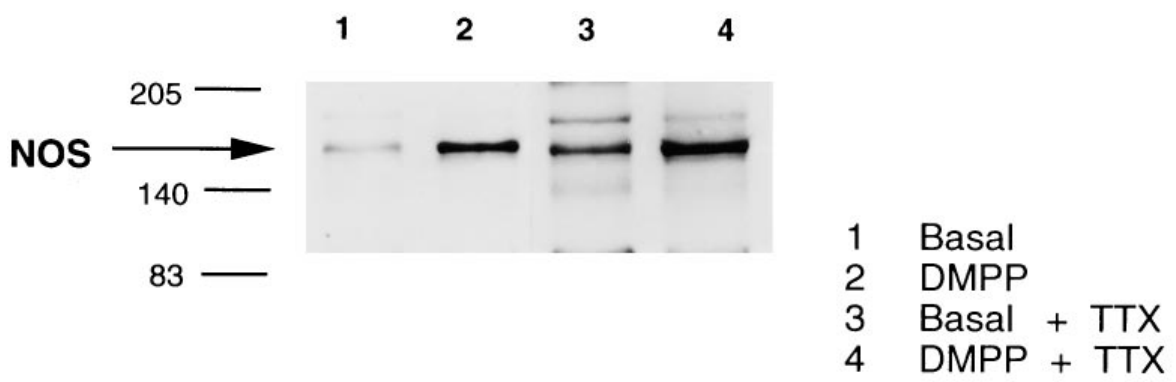

NOS mRNA $\longrightarrow$
Figure 8. Effects of DMPP $\left(10^{-8} \mathrm{M}\right)$ on nNOS synthesis and nNOS mRNA expression in the absence (lanes 1 and 2) or presence (lanes 3 and 4$)$ of TTX $\left(10^{-7} \mathrm{M}\right)$ in cultured myenteric ganglia. Incubation with DMPP $\left(10^{-8} \mathrm{M}\right)$ for $24 \mathrm{~h}$ caused a significant increase in the density of immunoreactive NOS bands at $155 \mathrm{kD}$ (lane 2). nNOS synthesis stimulated by DMPP was not affected by TTX (lane 4 ). The density of nNOS mRNA bands at $9.5 \mathrm{~kb}$ was also increased by a 24-h incubation with DMPP $\left(10^{-8} \mathrm{M}\right)$ (lane 2$)$, but was not affected by TTX (lane 4). crease $(208 \pm 27 \%$ of basal $)$ in the density of the immunoreactive nNOS bands at $155 \mathrm{kD}$. Treatment of the cultured gastric myenteric ganglia with TTX $\left(10^{-7} \mathrm{M}\right)$ did not affect DMPP $\left(10^{-8} \mathrm{M}\right)$-stimulated nNOS-immunoreactive bands (Fig. 8).

Northern blot analysis of NOS mRNA in the cultured gastric myenteric plexus. Incubation with DMPP $\left(10^{-8} \mathrm{M}\right)$ for $24 \mathrm{~h}$ also stimulated nNOS mRNA expression. Treatment with TTX did not affect this response (Fig. 8).

Incubation with DMPP $\left(10^{-10}-10^{-7} \mathrm{M}\right)$ for $24 \mathrm{~h}$ provoked a dose-dependent increase in nNOS mRNA expression. A maximum effect was observed with DMPP at $10^{-8} \mathrm{M}(245 \pm 36 \%$ of basal) (Fig. 9).

DMPP $\left(10^{-8} \mathrm{M}\right)$-stimulated nNOS mRNA expression was maximal after a 48 -h incubation. The increase was $282 \pm 32 \%$ of basal (Fig. 10). Prolonged exposure with DMPP ( $>48 \mathrm{~h}$ ) reduced nNOS mRNA expression, suggesting that desensitization to DMPP occurred in the gastric myenteric plexus.

nNOS mRNA expression stimulated by DMPP was antagonized by the protein kinase $\mathrm{C}$ (PKC) antagonist bisindolyl- maleimide, the PLC inhibitor U73122, and the intracellular $\mathrm{Ca}^{2+}$ chelator BAPTA/AM. In contrast, the tyrosine kinase inhibitor genistein had no effect on DMPP-stimulated nNOS mRNA expression (Fig. 11).

\section{Discussion}

Recently, we demonstrated that the gastric accommodation reflex is mediated by the vagal efferent pathways and nicotinic synapses using NO released from the gastric myenteric plexus, resulting in gastric relaxation $(17,20)$. In this study, we investigated if the synthesis and gene expression of NOS in the gastric myenteric plexus are also regulated by the vagal nerve and nicotinic synapses. We evaluated NANC relaxation, the number of NOS-immunoreactive cells and NADPH diaphorasepositive cells, and the catalytic activity of NOS, NOS synthesis, and NOS mRNA expression in the gastric myenteric plexus after vagotomy or nicotinic receptor blockade.

As previously described (6), NANC relaxation in response
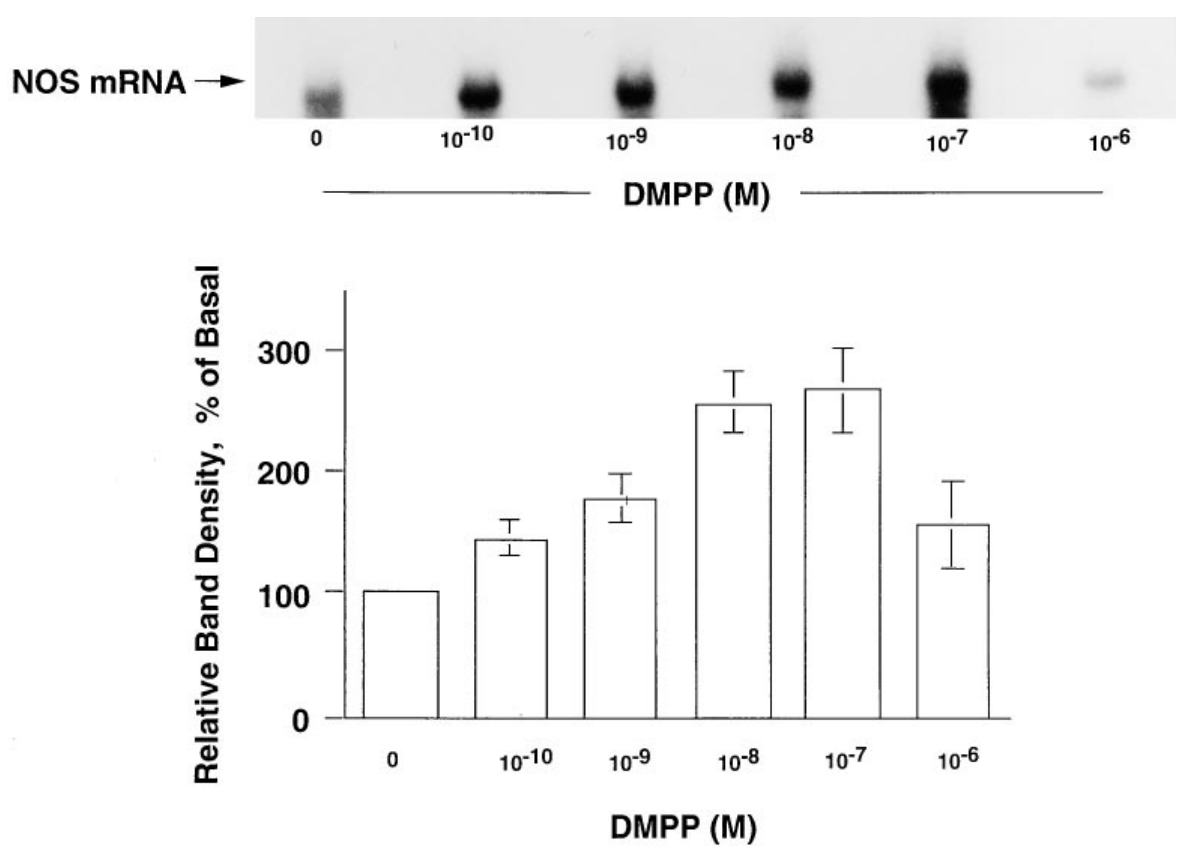

Figure 9. Dose-response study of DMPPstimulated nNOS mRNA expression in cultured gastric myenteric ganglia. Incubation with DMPP $\left(10^{-10}-10^{-7} \mathrm{M}\right)$ for $24 \mathrm{~h}$ caused a dose-dependent increase in nNOS mRNA expression. Maximum effect was observed with $10^{-8}$ M DMPP, which stimulated a $245 \pm 36 \%$ increase of basal (mean \pm SE, $n=4)$. 


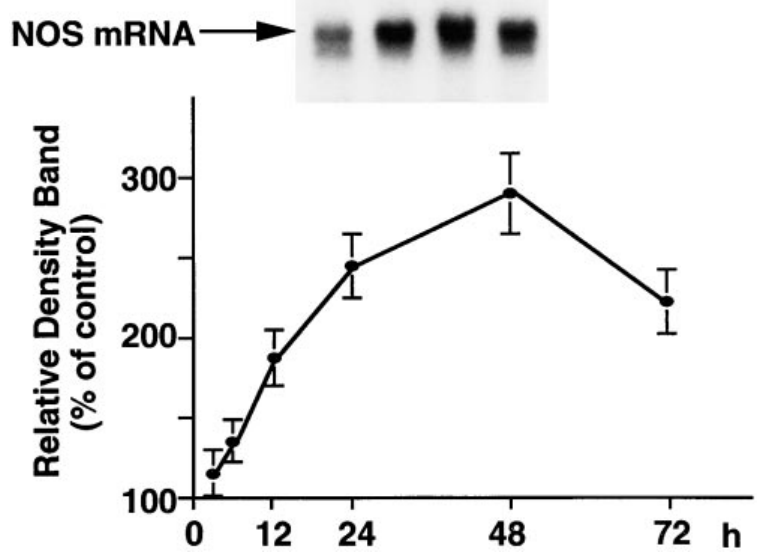

Figure 10. Time course of nNOS mRNA expression stimulated by DMPP $\left(10^{-8} \mathrm{M}\right)$ in cultured gastric myenteric ganglia. nNOS mRNA expression was maximum after a 48-h incubation period, resulting in a $282 \pm 32 \%$ increase of basal (mean \pm SE, $n=3$ ).

to transmural stimulation was significantly antagonized by L-NAME and abolished by TTX in muscle strips from the gastric body. This suggests mediation by neural release of NO from the gastric myenteric plexus. NANC relaxation was significantly impaired in the muscle strips from vagotomized rats and hexamethonium-treated rats. In contrast, gastric relaxation evoked by exogenous SNP was not affected in these preparations. This suggests that the sensitivity of the muscle cells to NO remains unaffected after vagotomy and nicotinic receptor blockade, and that the vagal nerve and nicotinic synapses are important factors in mediating the integrity of the NO pathway in the gastric myenteric plexus.

NO is synthesized from L-arginine by NOS. NOS has been classified into two categories: constitutive NOS is found in the cerebellum and vascular endothelium and is $\mathrm{Ca}^{2+} /$ calmodulindependent; inducible NOS (iNOS) is found in macrophages, hepatocytes, vascular endothelia, and smooth muscle cells and is $\mathrm{Ca}^{2+}$ /calmodulin-independent (37). In our previous studies, NO synthesis in response to electrical stimulation was completely abolished by pretreatment with a $\mathrm{Ca}^{2+}$-free medium (20), suggesting that the constitutive form of NOS is found in the gastric myenteric plexus. The catalytic activity of NOS in gastric tissue from sham-operated rats and vehicle-treated rats was completely abolished by incubation with $\mathrm{Ca}^{2+}$-free medium or L-NAME. Catalytic activity of NOS was significantly reduced in the gastric tissue from vagotomized rats and hexamethonium-treated rats. However, ${ }^{3} \mathrm{H}$-citrulline formation does not distinguish between NO generated from nNOS in the nerves and eNOS in the smooth muscle cells (38) or endothelia (36) of gastric tissue. Therefore, we performed nNOS immunohistochemistry and Western blot analysis of gastric tissue using nNOS antibody. nNOS antibody has been shown to have no cross-reactivity with eNOS antibody or with iNOS (39). We showed that the number of NOS-immunoreactive cells was reduced significantly in the gastric myenteric plexus of vagotomized rats and hexamethonium-treated rats. In contrast, the number of PGP 9.5-immunoreactive cells was unaffected, suggesting that vagotomy and nicotinic receptor blockade do not affect the generic neurons in the gastric myenteric plexus.

It has been demonstrated that nNOS is highly expressed in rat cerebellum $(1,30,40)$. The immunoreactive bands at $155 \mathrm{kD}$ obtained from gastric tissues corresponded well with the bands obtained from rat cerebellum, suggesting that nNOS in the gastric myenteric plexus is similar to nNOS in the central nervous system. The density of immunoreactive bands of nNOS was significantly reduced in the gastric tissue from vagotomized rats. This may be the result of changes in transcription, translation, or posttranslation.

We investigated the effect of vagotomy or hexamethonium on nNOS mRNA expression in the gastric myenteric plexus.
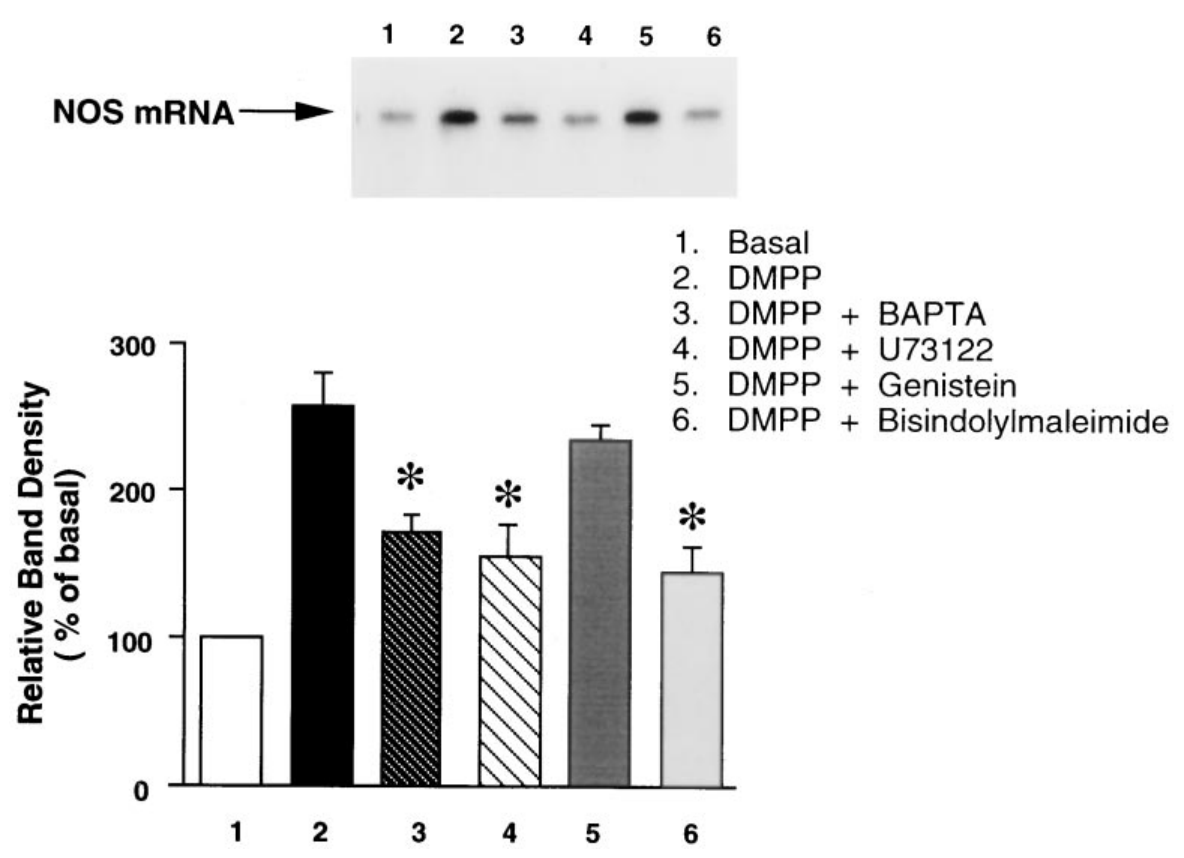

Figure 11. Effects of various antagonists on DMPP-stimulated nNOS mRNA expression in cultured gastric myenteric ganglia. nNOS mRNA expression evoked by DMPP $\left(10^{-8} \mathrm{M}\right)$ was significantly reduced by BAPTA/AM $\left(10^{-5} \mathrm{M}\right)$ (lane 3$)$, U73122 $\left(10^{-5} \mathrm{M}\right)$ (lane 4), and bisindolylmaleimide $\left(10^{-5} \mathrm{M}\right)$ (lane 6$)$, but not by genistein $\left(10^{-5} \mathrm{M}\right)$ (lane 5). Mean $\pm \mathrm{SE}$, $n=4, * P<0.05$ by Bonferroni. 


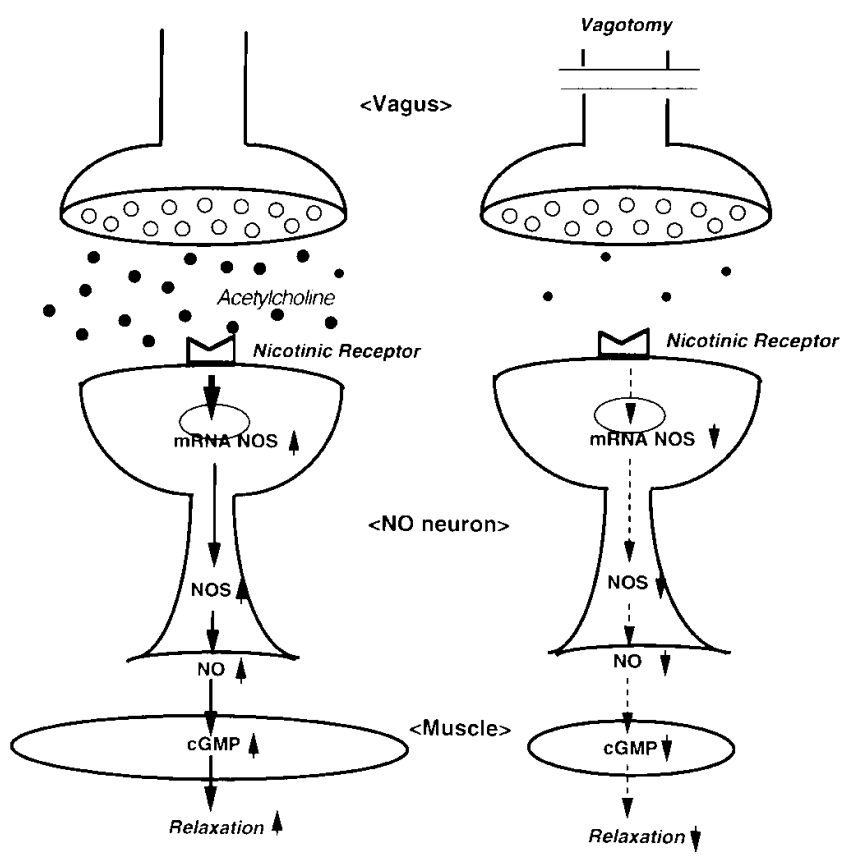

Figure 12. Proposed mechanism of impaired nNOS expression in the gastric myenteric plexus after vagotomy. Vagal release of acetylcholine from the nerve terminal of preganglionic fibers regulates the gene expression and synthesis of nNOS in the gastric myenteric plexus through nicotinic synapses. Reduced cholinergic stimulation in the myenteric plexus after vagotomy results in decreased nNOS mRNA expression, nNOS synthesis, NO production, and NANC relaxation.

The density of nNOS mRNA bands at $9.5 \mathrm{~kb}$ was significantly reduced in the gastric tissue from vagotomized rats and hexamethonium-treated rats, compared with sham-operated rats and vehicle-treated rats. This indicates that the reduced nNOS synthesis observed in the gastric tissue from vagotomized rats and hexamethonium-treated rats was caused by impaired gene transcription of nNOS.

We demonstrated previously that the activation of nNOS in the gastric myenteric plexus is under vagal regulation through nicotinic synapses (20). Studies have shown that membrane depolarization does not only cause rapid alternations in protein phosphorylation; it also activates new programs of gene expression in neuronal cells (41). We propose that nicotinic receptor stimulation provokes expression of nNOS mRNA and activation of nNOS in the gastric myenteric plexus. The release of acetylcholine from nerve terminals of preganglionic fibers generates the gene expression and synthesis of nNOS in the gastric myenteric plexus through nicotinic synapses. Reduction of cholinergic stimulation to the myenteric plexus after vagotomy results in decreased nNOS mRNA expression, nNOS synthesis, NO release, and NANC relaxation (Fig. 12). This may explain the impaired accommodation reflex observed in patients after truncal vagotomy $(18,42)$.

Various regulatory elements for the expression of iNOS or eNOS have been characterized. Synthesis of iNOS in murine macrophages is stimulated by LPS and IFN- $\gamma(43,44)$. In human hepatocytes, iNOS mRNA is induced by treatment with TNF, IL-1, IFN- $\gamma$, and LPS (45-47). Expression of iNOS
mRNA is regulated by cAMP in rat vascular smooth muscle cells (48) and by c-fos in insulin-producing cells (49). Expression of eNOS mRNA in cultured bovine aortic endothelial cells was not increased by coincubation with TNF, but was markedly increased by exposure to shear stress for $24 \mathrm{~h} \mathrm{(50).}$ Chronic exercise in dogs increases coronary vascular NO production and eNOS gene expression (51).

The regulatory mechanism of nNOS expression is not known. Hammer et al. (52) proposed that prolonged activation of brain $N$-methyl-D-aspartic acid (NMDA) receptors increases intraneuronal $\mathrm{Ca}^{2+}$ concentration and nNOS synthesis in rat dorsolateral striata. Using an in situ hybridization technique, Valerie et al. (53) reported that nerve sectioning induced a dramatic increase in the number of nNOS mRNApositive cells in the dorsal root ganglia. The plasticity of NO synthesizing neurons has been demonstrated in the ileal myenteric plexus after extrinsic denervation (54) and in dorsal root ganglia after axotomy (53). The number of NADPH diaphorase-positive cells increased after extrinsic denervation of the rat ileum (55), resulting in enhanced NANC relaxation (54). We have shown recently that nNOS expression of the myenteric plexus in rat small intestine is independent of the vagal nerve, but is negatively controlled by the splanchnic nerve (62). Western blot analysis and Northern blot analysis showed a significant increase in NOS and NOS mRNA expression, respectively, in the myenteric plexus of rats treated with splanchnic ganglionectomy and 6-OH-dopamine, but not in the myenteric plexus of rats treated with truncal vagotomy (56). In contrast, there was a significant reduction in nNOS expression after truncal vagotomy in the rat gastric myenteric plexus in this study. It has been demonstrated that the distribution of vagal efferent fibers is significantly different between the stomach and the intestine in rats (57). Ganglia in the myenteric plexus innervated by vagal efferent fibers are more numerous in the stomach than in the small intestine. Vagal innervation of ganglia in the small intestine becomes progressively more sparse distally. In fact, $\sim 80 \%$ of the myenteric neurons in the duodenum are not innervated by vagal efferents (57). This difference in distribution of vagal efferents may explain the differential effects of extrinsic denervation on nNOS expression between the stomach and small intestine.

In this study using isolated cultured gastric myenteric ganglia, the number of nNOS-immunoreactive cells was increased by incubation with the nicotinic receptor agonist, DMPP. We also demonstrated that incubation of the cultured gastric myenteric ganglia with DMPP induced a dose-dependent increase in nNOS mRNA expression. These results strongly suggest that activation of nicotinic synapses stimulates nNOS expression in the rat gastric myenteric plexus. The isolated gastric myenteric ganglia preparation is a heterogeneous population of neuronal cells. It is not clear if DMPP acts directly or indirectly by releasing other neurotransmitters, which in turn affect nNOS synthesis. DMPP-stimulated nNOS synthesis and nNOS mRNA expression were not affected by TTX in the cultured gastric myenteric plexus, which strongly suggests that DMPP directly stimulates nNOS mRNA expression and nNOS synthesis in the gastric myenteric plexus.

The role of PKC on iNOS expression has been the focus of intense investigation. Angiotensin II upregulates IL- $1 \beta$-induced iNOS mRNA expression in cardiac myocytes by activating PKC (58). LPS stimulates myocyte PKC activity, iNOS expression, and NOS activity. Direct activation of PKC with $\beta$-phor- 
bol 12,13-dibutyrate induced myocyte iNOS synthesis and NOS activity, and reduced electrically stimulated contractility (59). These findings suggest that PKC is a significant intracellular mediator for iNOS expression and contractility in cardiac myocytes. The role of PKC in the induction of iNOS by IFN- $\gamma$ has also been demonstrated in murine macrophage cell lines $(43,44)$.

Although nNOS is activated by a $\mathrm{Ca}^{2+}$-dependent PKC pathway in the central nervous system (60-62), it remains unknown if a PKC pathway is involved in regulating nNOS mRNA expression in the myenteric plexus. In this study, incubation with PMA significantly increased the number of nNOSimmunoreactive cells in the cultured gastric myenteric plexus. We also demonstrated that DMPP-stimulated nNOS mRNA expression was antagonized by the PKC antagonist bisindolylmaleimide, the PLC inhibitor U73122, and the intracellular $\mathrm{Ca}^{2+}$ chelator BAPTA/AM. In contrast, the tyrosine kinase inhibitor genistein had no effect on nNOS mRNA expression stimulated by DMPP. These studies suggest that nNOS gene expression and its synthesis in the gastric myenteric plexus are upregulated by nicotinic receptor activation, which stimulates the phosphoinositol cascade, which in turn, activates a $\mathrm{Ca}^{2+}$ dependent PKC pathway.

The role of NO in the mediation of the gastric accommodation reflex is well established $(17,63)$. This neural pathway may play an important role in the regulation of gastric motility. An understanding of the mechanism that regulates nNOS gene expression and synthesis in the gastric myenteric plexus may elucidate the cellular mechanisms mediating gastric motor function.

\section{Acknowledgments}

The authors gratefully acknowledge Dr. Solomon H. Snyder (The Johns Hopkins University School of Medicine, Baltimore, MD) for providing nNOS cDNA. The authors also thank Gary Blum, Luke Saski, Ken Berman, Marcus Campbell, and Jennifer Thomas for their excellent technical assistance. The authors would like to thank Professor M. Mori (The First Department of Internal Medicine, Gunma University School of Medicine, Maebashi, Japan) for lending his support to Dr. K. Nakamura during his training at the University of Michigan, June 1995 to March 1996.

This study was supported by The Juvenile Diabetes Foundation International (File No. 194180, T. Takahashi) and the National Institute of Diabetes and Digestive and Kidney Diseases (grants RO1 DK-39199 and P30 DK-39433, C. Owyang).

\section{References}

1. Bredt, D.S., P.M. Hwang, and S.H. Snyder. 1990. Localization of nitric oxide synthase indicating a neural role for nitric oxide. Nature. 347:768-770.

2. Aimi, Y., H. Kimura, T. Kinoshita, Y. Minami, M. Fujimura, and S.R. Vincent. 1993. Histochemical localization of nitric oxide synthase in rat enteric nervous system. Neuroscience. 53:553-560.

3. Mearin, F., M. Mourelle, F. Guarner, A. Sales, V. Riveros-Moreno, S. Moncada, and J.-R. Malgelada. 1993. Patients with achalasia lack nitric oxide synthase in the gastro-oesopageal junction. Eur. J. Clin. Invest. 23:724-728.

4. Singaram, C., A. Sengupta, M. Sweet, M. Reichelderfer, and R. Goyal. 1994. Selective loss of nitrinergic and CGRP innervation in esophageal achalasia. Gastrointestinal Motility. 106:218A. (Abstr.)

5. Vanderwinden, J.-M., P. Mailleux, S. Schiffmann, J.-J. Vanderhaeghen, and M.-H. De Laet. 1992. Nitric oxide synthase activity in infantile hypertrophic pyloric stenosis. N. Engl. J. Med. 327:511-515.

6. Takahashi, T., K. Nakamura, H. Itoh, A.A.F. Sima, and C. Owyang. 1997. Impaired gene expression of nitric oxide synthase in the gastric myenteric plexus of spontaneously diabetic BB/W rats. Gastroenterology. 113:1535-1544.

7. Solar, N. 1980. Diabetic gastroparesis without autonomic neuropathy. $\mathrm{Di}$ - abetes Care. 3:200-201.

8. Russel, C., F.J. Ganman, R. Coatsworth, R. Neilsen, A.L. Hill, and I.C Pope. 1983. Relationship among esophageal dysfunction, diabetic gastroenteropathy, and peripheral enteropathy. Dig. Dis. Sci. 28:289-293.

9. Keshavarzian, A., F.L. Lber, and B.A. Vaeth. 1987. Gastric emptying in patients with insulin requiring diabetes mellitus. Am. J. Gastroenterol. 82:29-35.

10. Cannon, W.B., and C.W. Lieb. 1911. The receptive relaxation of the stomach. Am. J. Physiol. 29:267-273.

11. Grey, E.G. 1917. Observations on the postural activity of the stomach. Am. J. Physiol. 45:272-285.

12. Abrahamsson, H., and G. Jansson. 1969. Elicitation of reflex vagal relaxation of the stomach from pharynx and esophagus in the cat. Acta Physiol. Scand. 77:172-178.

13. Wilbur, B., and K. Kelly. 1973. Effect of proximal gastric, complete gastric, and truncal vagotomy on canine gastric electric activity, motility, and emptying. Ann. Surg. 178:295-303.

14. Jahnberg, T., H. Abrahamsson, G. Jansson, and J. Martinson. 1977. Vagal gastric relaxation in the dog. Scand. J. Gastroenterol. 12:221-224.

15. Andrews, P., D. Grundy, and I. Lawes. 1980. The role of the vagus and splanchnic nerves in the regulation of intragastric pressure in the ferret.J. Physiol. (Lond.). 307:401-411.

16. Takasugi, S., T. Ueda, Y. Kurata, M. Kodama, H. Ezaki, and K. Fujii. 1982. Neural and humoral factors influence gastric receptive relaxation in dogs. Jpn. J. Surg. 12:208-213.

17. Takahashi, T., and C. Owyang. 1997. Characterization of vagal pathways mediating gastric accommodation reflex in rats. J. Physiol. (Lond.). 504: $479-488$.

18. Troncon, L.E.A., D.G. Thompson, N.K. Ahluwalia, J. Barlow, and L. Heggie. 1995. Relations between upper abdominal symptoms and gastric distension abnormalities in dysmotility like functional dyspepsia and after vagotomy. Gut. 37:17-22.

19. Sunaga, K., and M. Ogihara. 1990. Effects of calcium channel blockers and hydralazine on plasma glucose levels in streptozotocin-induced diabetic rats in vivo. Jpn. J. Pharmacol. 52:449-455.

20. Takahashi, T., and C. Owyang. 1995. Vagal control of gastric motility: participation of nitric oxide and vasoactive intestinal polypeptide in the regulation of gastric relaxation. J. Physiol. (Lond.). 484:481-492.

21. Takahashi, T., M. Kusunoki, M. Kantoh, T. Yamamura, and J. Utsunomiya. 1988. Effects of cholecystokinin-octapeptide on contractile motility of guinea pig common bile duct. Am. J. Physiol. 254:G819-G823.

22. Takahashi, T., S. Kurosawa, J. Wiley, and C. Owyang. 1991. Mechanism for the gastrokinetic action of domperidone; in vitro studies in guinea pigs. Gastroenterology. 101:703-710.

23. Boeckxstaens, G.E., P.A. Pelckmans, J.J. Bogers, H. Bult, J.G. De Man, L. Oosterbosch, A.G. Herman, and Y.M. Van Maercke. 1991. Release of nitric oxide upon stimulation of nonadrenergic noncholinergic nerves in the rat gastric fundus. J. Pharmacol. Exp. Ther. 256:441-447.

24. Nowak, T., B. Harrington, J. Kalbfleisch, and J. Amatruda. 1986. Evidence for abnormal cholinergic neuromuscular transmission in diabetic rat small intestine. Gastroenterology. 91:124-132.

25. Belai, A., H.H. Schmidt, C.H. Hoyle, C.J. Hassall, M.J. Saffrey, J. Moss, U. Forstermann, F. Murad, and G. Burnstock. 1992. Colocalization of nitric oxide synthase and NADPH-diaphorase in the myenteric plexus of the rat gut. Neurosci. Lett. 143:60-64.

26. Tracey, W., M. Nakane, J. Pollock, and U. Forstermann. 1993. Nitric oxide synthases in neuronal cells, macrophages and endothelium are NADPH diaphorases, but represent only a fraction of total cellular NADPH diaphorase activity. Biochem. Biophys. Res. Commun. 195:1035-1040.

27. Eaker, E.Y., and J.E. Sallustio. 1994. The distribution of novel intermediate filament proteins defines subpopulations of myenteric neurons in rat intestine. Gastroenterology. 107:666-674.

28. Matsumoto, T., J.A. Mitchell, H.H.H.W. Schmidt, K.L. Kohlhaas, T.D. Warner, U. Forstermann, and F. Murad. 1992. Nitric oxide synthase in ferret brain: localization and characterization. Br. J. Pharmacol. 107:849-852.

29. Huang, P.L., T.M. Dawson, D.S. Bredt, S.H. Snyder, and M.C. Fishman. 1993. Targeted disruption of the neuronal nitric oxide synthase gene. Cell. 75 : 1273-1286.

30. Bredt, D.S., P.H. Hwang, C.E. Glatt, C. Lowenstein, R.R. Reed, and S.H. Snyder. 1991. Cloned and expressed nitric oxide synthase structurally resembles cytochrome P-450 reductase. Nature. 351:714-718.

31. Takahashi, T., Y. Tsunoda, Y. Lu, J. Wiley, and C. Owyang. 1992. Release of acetylcholine and somatostatin in the myenteric plexus evoked by nicotinic receptor stimulation is mediated by voltage sensitive N-type calcium channel. J. Pharmacol. Exp. Ther. 263:1-5.

32. Kalberg, C., S.Y. Yung, and J.A. Kessler. 1993. The cholinergic stimulating effects of ciliary neurotrophic factor and leukemia inhibitory factor are mediated by protein kinase C. J. Neurochem. 60:145-152

33. Freidin, M., M.V. Bennett, and J.A. Kessler. 1992. Cultured sympathetic neurons synthesize and release the cytokine interleukin 1 beta. Proc. Natl. Acad. Sci. USA. 89:10440-10443.

34. Christofi, F.L., M. Hanani, N. Maudlej, and J.D. Wood. 1993. Enteric glial cells are major contributors to formation of cyclic AMP in myenteric 
plexus cultures from adult guinea-pig small intestine. Neurosci. Lett. 159:107-110 35. Lindsay, R.M., and A.J. Harmar. 1989. Nerve growth factor regulates expression of neuropeptide genes in adult sensory neurons. Nature. 337:362-364.

36. Forstermann, U., J.S. Pollock, W.R. Tracey, and M. Nakane. 1994. Isoforms of nitric-oxide synthase: purification and regulation. Methods Enzymol. 233:258-264.

37. Marletta, M.A. 1993. Nitric oxide synthase structure and mechanism. $J$. Biol. Chem. 268:12231-12234.

38. Teng, B., K. Murthy, J. Kuemmerle, J. Grider, and G. Makhlouf. 1996. Expression of constitutive endothelial nitric oxide synthase (eNOS) in rabbit and human gastrointestinal smooth muscle cells. Gastroenterology. 110:1125A (Abstr).

39. Saffrey, M.J., C.J. Hassall, C.H. Hoyle, A. Belai, J. Moss, H.H. Schmidt, U. Forstermann, F. Murad, and G. Burnstock. 1992. Colocalization of nitric oxide synthase and NADPH-diaphorase in cultured myenteric neurones. Neuroreport. 3:333-336.

40. Bredt, D.S., C.E. Glatt, P.M. Hwang, M. Fotuhi, T.M. Dawson, and S.H. Snyder. 1991. Nitric oxide synthase protein and mRNA are discretely localized in neuronal populations of the mammalian CNS together with NADPH diaphorase. Neuron. 7:615-624.

41. Tolon, R., F. Franco, M. Fraalies, M. Lorenzo, and L. Cacicedo. 1994. Effect of potassium-induced depolarization on somatostatin gene expression in cultured fetal rat cerebrocortical cells. J. Neurosci. 14:1053-1059.

42. Jahnberg, T., J. Martinson, L. Hulten, and S. Fasth. 1975. Dynamic gastric response to expansion before and after vagotomy. Scand. J. Gastroenterol. 10:593-598.

43. Severn, A., M.J. Wakelam, and F.Y. Liew. 1992. The role of protein kinase $\mathrm{C}$ in the induction of nitric oxide synthesis by murine macrophages. Biochem. Biophys. Res. Commun. 188:997-1002.

44. Sharma, K., T.M. Danoff, A. DePiero, and F.N. Ziyadeh. 1995. Enhanced expression of inducible nitric oxide synthase in murine macrophages and glomerular mesangial cells by elevated glucose levels: possible mediation via protein kinase C. Biochem. Biophys. Res. Commun. 207:80-88.

45. Geller, D.A., C.J. Lowenstein, R.A. Shapiro, A.K. Nussler, M. Di Silvio, S.C. Wang, D.K. Nakayama, R.L. Simmons, S.H. Snyder, and T.R. Billiar. 1993. Molecular cloning and expression of inducible nitric oxide synthase from human hepatocytes. Proc. Natl. Acad. Sci. USA. 90:3491-3495.

46. Geller, D.A., M. Di Silvio, A.K. Nussler, S.C. Wang, R.A. Shapiro, R.L. Simmons, and T.R. Billiar. 1993. Nitric oxide synthase expression is induced in hepatocytes in vivo during hepatic inflammation. J. Surg. Res. 55:427-432.

47. Geller, D.A., A.K. Nussler, M. Di Silvio, C.J. Lowenstein, R.A. Shapiro, S.C. Wang, R.L. Simmons, and T.R. Billiar. 1993. Cytokines, endotoxin, and glucocorticoids regulate the expression of inducible nitric oxide synthase in hepatocytes. Proc. Natl. Acad. Sci. USA. 90:522-526.

48. Imai, T., Y. Hirata, K. Kanno, and F. Marumo. 1994. Induction of nitric oxide synthase by cyclic AMP in rat vascular smooth muscle cells. J. Clin. Invest. 93:543-549.
49. Eizirik, D., A. Bjorklund, and N. Welsh. 1993. Interleukin-1-induced expression of nitric oxide synthase in insulin-producing cells is preceded by c-fos induction and depends on gene transcription and protein synthesis. FEBS Lett. 317:62-66.

50. Nishida, K., D.G. Harrison, J.P. Navas, A.A. Fisher, S.P. Dockery, M. Uematsu, R.M. Nerem, R.W. Alexander, and T.J. Murphy. 1992. Molecular cloning and characterization of the constitutive bovine aortic endothelial cell nitric oxide synthase. J. Clin. Invest. 90:2092-2096.

51. Sessa, W.C., K. Pritchard, N. Seyedi, J. Wang, and T.H. Hintze. 1994 Chronic exercise in dogs increases coronary vascular nitric oxide production and endothelial cell nitric oxide synthase gene expression. Circ. Res. 74:349-353.

52. Hammer, B., W.D. Parker, Jr., and J.P. Bennett, Jr. 1993. NMDA receptors increase $\mathrm{OH}$ radicals in vivo by using nitric oxide synthase and protein kinase C. Neuroreport. 5:72-74.

53. Valerie, M., K. Verge, Z Xu, X.J. Xu, Z. Wiesenfeld-Hallin, and T. Hokfelt. 1992. Marked increase in nitric oxide synthase mRNA in rat dorsa root ganglia after peripheral axotomy; in situ hybridization and functional studies. Proc. Natl. Acad. Sci. USA. 89:11617-11621.

54. Yunker, A., and J. Galligan. 1994. Anatomical and functional evidence for increased nitric oxide synthase (NOS) after extrinsic denervation of guinea pig ileum. Gastroenterology. 106:1057A. (Abstr.)

55. Yunker, A.M., and J.J. Galligan. 1994. Extrinsic denervation increases NADPH diaphorase staining in myenteric nerves of guinea pig ileum. Neurosci. Lett. 167:51-54.

56. Nakao, K., T. Takahashi, J. Utsunomiya, and C. Owyang. 1998. Extrinsic neural control of nitric oxide synthase expression in the myenteric plexus of rat jejunum. J. Physiol. (Lond.). In press.

57. Kirchgessner, A.L., and M.D. Gershon. 1989. Identification of vagal efferent fibers and putative target neurons in the enteric nervous system of the rat. J. Comp. Neurol. 285:38-53.

58. Ikeda, U., Y. Maeda, Y. Kawahara, M. Yokoyama, and K. Shimada. 1995. Angiotensin II augments cytokine-stimulated nitric oxide synthesis in rat cardiac myocytes. Circulation. 92:2683-2689.

59. McKenna, T.M., S. Li, and S. Tao. 1995. PKC mediates LPS- and phorbol-induced cardiac cell nitric oxide synthase activity and hypocontractility. Am. J. Physiol. 269:H1891-H1898.

60. Yuan, Y., H. Gardner, D. Zawieja, D. DeFily, and W. Chillian. 1993. Histamine increases venular permeability via a phospholipase C-NO synthaseguanylate cyclase cascade. Am. J. Physiol. 264:H1734-H1739.

61. Bredt, D., C. Ferris, and S. Snyder. 1992. Nitric oxide synthase regulatory sites. J. Biol. Chem. 267:10976-10981.

62. Okada, D. 1995. Protein kinase C modulates calcium sensitivity of nitric oxide synthase in cerebellar slices. J. Neurochem. 64:1298-1304.

63. Desai, K.M., W.C. Sessa, and J.R. Vane. 1991. Involvement of nitric oxide in the reflex relaxation of the stomach to accommodate food or fluid. $\mathrm{Na}$ ture. 351:477-479. 